\title{
Statyba
}

\section{PROJECT SYNTHESIS USING COMPROMISE- COMPENSATING MODEL IN DECISION SUPPORT SYSTEM IN CONSTRUCTION INDUSTRY}

\section{V. Šarka , L. Ustinovičius Doctor (technical sciences) \& E. K. Zavadskas}

To cite this article: V. Šarka , L. Ustinovičius Doctor (technical sciences) \& E. K. Zavadskas (1999) PROJECT SYNTHESIS USING COMPROMISE-COMPENSATING MODEL IN DECISION SUPPORT SYSTEM IN CONSTRUCTION INDUSTRY, Statyba, 5:6, 374-385, DOI: 10.1080/13921525.1999.10531492

To link to this article: https://doi.org/10.1080/13921525.1999.10531492

$$
\text { 曲 Published online: } 26 \text { Jul } 2012 .
$$

Submit your article to this journal $₫$

Џll Article views: 95

Citing articles: 2 View citing articles 


\section{PROJEKTU SINTEZE் NAUDOJANT KOMPROMISO KOMPENSACINIUS MODELIUS STATYBOJE}

\section{V. Šarka, L. Ustinovičius, E. K. Zavadskas}

\section{Ivadas}

Statybos procesas yra sudetingas kompleksas dideliu projektu, i kuriuos jeina tarpusavyje glaudžiai susiję smulkesni projektai bei uždaviniai.

Sprendimų efektyvumas tiesiogiai susijęs su patirtimi, turimos informacijos kiekiu ir jos kokybe, jau išnagrinètu ir igyvendintu projektų skaičiumi ir informacija apie juos. Sprendimus puikiai galima igyvendinti naudojant kompiuterinę irangą [1].

Jau yra sukurta ir yra kuriamos ịvairios sprendimų paramos sistemos (SPS), atliekami moksliniai ju skaičiavimai, tyrimai bei eksperimentai. Vienas iš naujausių darbų yra universalios sprendimų paramos sistemos statyboje (UniSPS) kūrimas. UniSPS statyboje suteikia vartotojui galimybę:

- naudotis ir papildyti esamą žinių bazę;

- sukurti ir visiškai valdyti naują žinių bazę;

- taikyti sistemoje užprogramuotus ekspertinius metodus, žaidimų teorijos metodus, apibendrintu kriteriju nuoseklaus optimizavimo, projektų daugiakriterinio kompleksinio ivertinimo metodus;

- taikyti pasiūlytus 3 naujus sintezès metodus;

- atlikti projekto dalių sistemotechninę analizę, siekiant norimo rezultato, iš karto koreguoti pradinius skaičiavimo duomenis;

- sudaryti visus galimus sprendimo prièmimo variantus, itraukti papildomus sprendimui priimti numatomus svarbius faktorius arba iš karto atmesti nereikalingus sprendinius;

- atlikti sudarytų projektų variantų sistemotechninę analizę, iš karto koreguoti pradinius skaičiavimo duomenis, siekiant norimo rezultato;

- peržiūrèti ir analizuoti gautus rezultatus, jvertinti teigiamas bei neigiamas projekto savybes, jei reikia, pataisius pradinius duomenis, atlikti papildomą sistemotechninę papildyto, pataisyto projekto analizę;
- projekto realizavimo eigoje atsiradus nenumatytiems atvejams (pasikeitus politinei situacijai, ivykus gaivalinei nelaimei ir $\mathrm{kt}$.), ivedus papildomų duomenu, efektyviai perskaičiuoti ir išanalizuoti susidariusią situaciją bei priimti reikiamus sprendimus;

- atlikti skaiciavimo ir galutinio realaus rezultato analizę bei nustatyti UniSPS atliekamy skaičiavimu realumo (patikimumo) koeficienta:

- sprendimu prièmimo srityje kelti ekspertu kvalifikacija.

\section{Sintezés metodų vieta sprendimų paramos sistemoje}

Sprendimy paramos sistema yra pagrista projektu sistemotechninio ivertinimo metodais (1 pav.) [2].

Projektų sistemotechniniam jvertinimui (PSI) taikomi ekspertiniai, daugiakriterinio optimizavimo ir žaidimu teorijos metodai. Sprendimui priimti naudojami bekompensaciniai ir kompensaciniai modeliai. Kompensaciniuose modeliuose, pablogejjus vienam kriterijui, projekto efektyvumo sumažéjimą galima kompensuoti gerinant $\mathrm{ji}$ pagal kitus kriterijus. Kiekvieną variantą apibūdinanti kriterijų sistema yra perskaixiuojama i vieną kriteriju, pagal kuri projektai yra lyginami ir išrenkamas geriausias [2].

Kompensaciniai modeliai skirstomi $\mathfrak{i}$ šias pagrindines grupes [2]:

1. Modeliai, kuriuose išrenkamas naudingiausias variantas. Pagrindiné ju problema - tinkamiausios naudingumo funkcijos nustatymas.

2. Modeliai, kuriuose išrenkamas daugiatikslis, artimiausias idealiam variantas.

3. Suderinamumo (konkordantiškumo) moduliai. Juose pateikiami prioritetiškumo santykiai, turintys didžiausią konkordantiškumo lygi.

Taigi trumpai apžvelgus ir atlikus trumpą analizę esamu moduliu, metodų bei išspręstų realių statybos proceso uždavinių [3], [2], [4], [5], taikant šiuos metodus, 


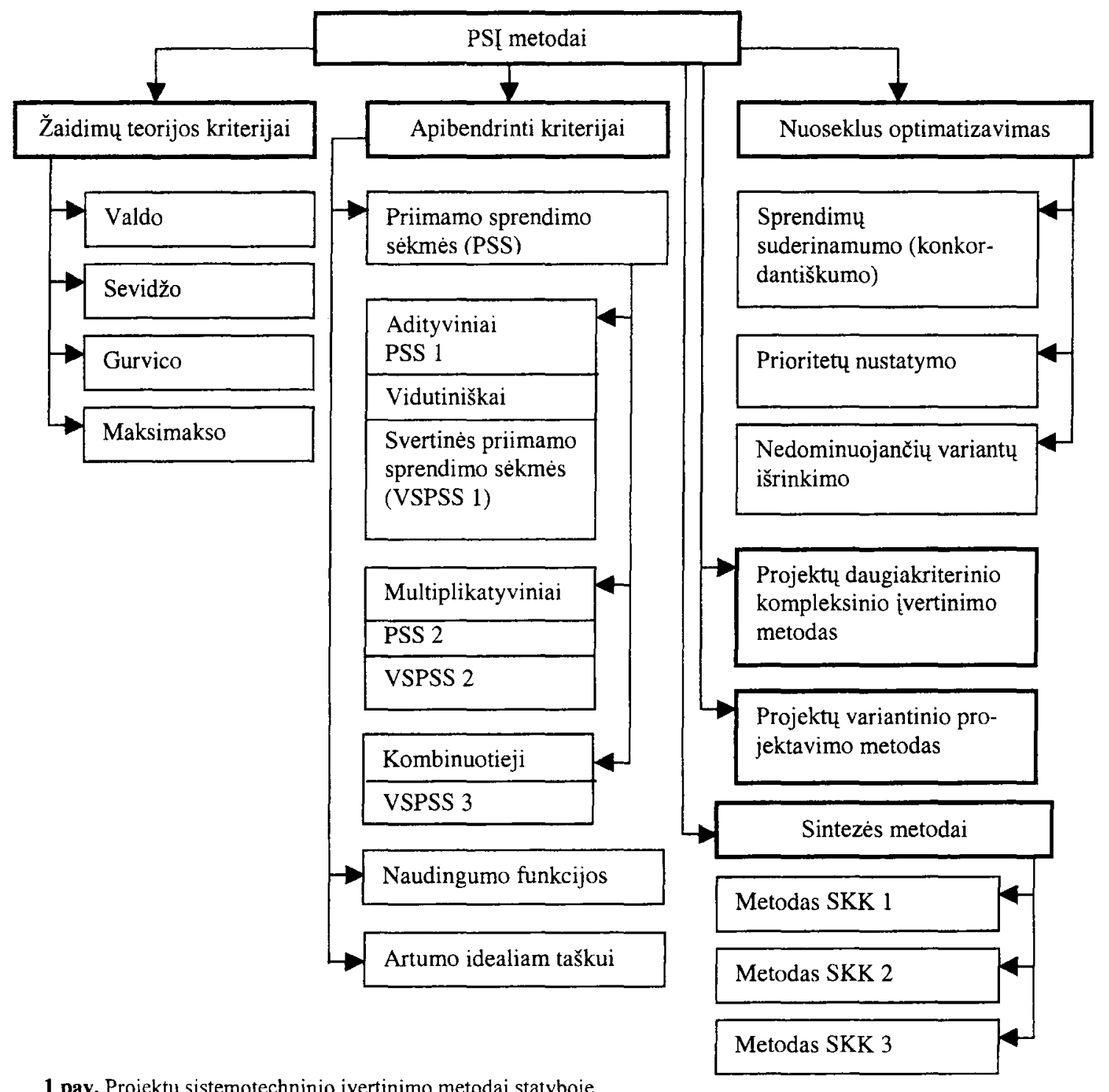

Fig 1. Projects multipurpose selectonovation methods in construction

daroma išvada, kad šie anksčiau pateikti metodai yra skirti etapiniams sprendimams priimti. Tačiau iškilus būtinybei atlikti papildomus skaičiavimus, duomenu bazès papildymus, reikia ịdeti daug darbo ir pastangu, t. y pakartotiniams skaičiavimams sugaištama daug laiko.

Atliekant daugiakriterini variantini projektavima dažnai reikia priimti sprendimą analizuojant, jungiant kelis uždavinius $\mathfrak{i}$ visumą. Taip yra atliekama kelių tarpusavyje susijusiu statybinių uždaviniu sintezé [6]. Kaip pasirodè toliau analizuojant galimus sprendimu variantus, galimi keli uždavinių sintezavimo variantai [7]:

1. Projektų efektyvumo lygis nustatomas, kai daliniai sprendimai skirtinguose etapuose yra priimami pagal skirtingas projektų rodiklių grupes, kurios skiriasi tiek savo tipu, tiek dimensijomis.
2. Projektu efektyvumo lygis nustatomas, kai daliniai sprendimai skirtinguose etapuose yra priimami pagal projektu rodikliu grupes, vienodas visiems priimamo sprendimo etapams.

Priimant atskirus sprendimus etapais ir pasirinkus variantini projektavima, bandant sujungti atskirus sprendimus į visumą yra prarandamas laikas, koregavimo galimybè ankstesniuose etapuose, mažèja bendro priimamo sprendimo efektyvumas. Tai yra patys svarbiausi momentai, nes laikas yra pinigai, o sprendimo efektyvumas - pagrindinis క̌ioms sistemoms keliamas uždavinys. Šių trūkumu galima išvengti, sprendimui priimti taikant sintezès metodus. 


\section{Projektų sintezès kompromiso kompensaciniu mo- \\ deliu metodas}

Visi minèti metodai skirti prïmti vieną ar kitą techninị sprendimą ivairiems etapams. Tačiau, kaip rodo statybos praktika, dažnai reikia spręsti statybinius uždavinius sintezuojant ịvairius techninius sprendimus (variantus) ir galutiniame variante sujungti juos i visuma. Tam ir yra taikomi trys nauji projektų sintezès metodai.

Ideja taikyti siuos metodus daugiakriteriniams sprendimams priimti pirmą kartą iškelta [7], tačiau tai nebuvo galutinai išnagrinèta ir pritaikyta naujai kuriamose sprendimu paramos sistemose statyboje.

Duomenų rinkimo procesą sudaro [4]:

- bendrosios informacijos apie analizuojamus variantus ir juos apibūdinančius kriterijus nustatymas;

- kriteriju sistemos sudarymas;

- kriteriju reikšmių ir pradinių reikšmingumų nustatymas;

- analizuojamų variantų ryšio su kitais projektais (ju sudetinemis dalimis) ar ji sudaranciais procesais ir sprendimais nustatymas.

Toliau šiame straipsnyje yra nagrinejamas projektu sintezès kompromiso kompensaciniu modeliu metodas. Šio metodo esmè - keliu susijusių techninių sprendimu sintezè, suderinant visus galimus variantus (ryšio matrica), kur laukiamas rezultatas $a_{s} \in A$. Metodo blokine schema pavaizduota 2 pav.

Pagal formulę (1) yra sumuojamos visu etapu kriterijų reikšmès.

$$
x_{s i}=\sum_{i=1, j=1}^{n, m} x_{i j}, i=\overline{1, n} ; j=\overline{1, m} ; s=\overline{1, d},
$$

čia $x_{s i}$ - etapo $s=\overline{1, d}$ normalizuotos sprendimų matri$\cos , i=\overline{1, n}$ varianto kriterijų reikšmių suma.

Taikant naudojant ši metodą galima ịvertinti kriterijų reikšmes, kurios atitinka visų etapų suderinamumo matricos reikalavimus, taip pat kriteriju reikšmingumus, kurie turi prasmę būti sumuojami per visus priimamo sprendimo etapus.

Pagal gautus sumavimo rezultatus kuriama sprendimu prièmimo matrica - variantu realizavimo laukiamų rezultatú matrica $[P]=\left[x_{i j}\right], i=\overline{1, n} ; j=\overline{1, m}$.

Variantų prioritetiškumui nustatyti taikomas artumo idealiam taškui metodas [2], [8].

1 etapas. Sudaroma normalizuota sprendimų matrica. Šio etapo tikslas - norint palyginti skirtingu dimensiju

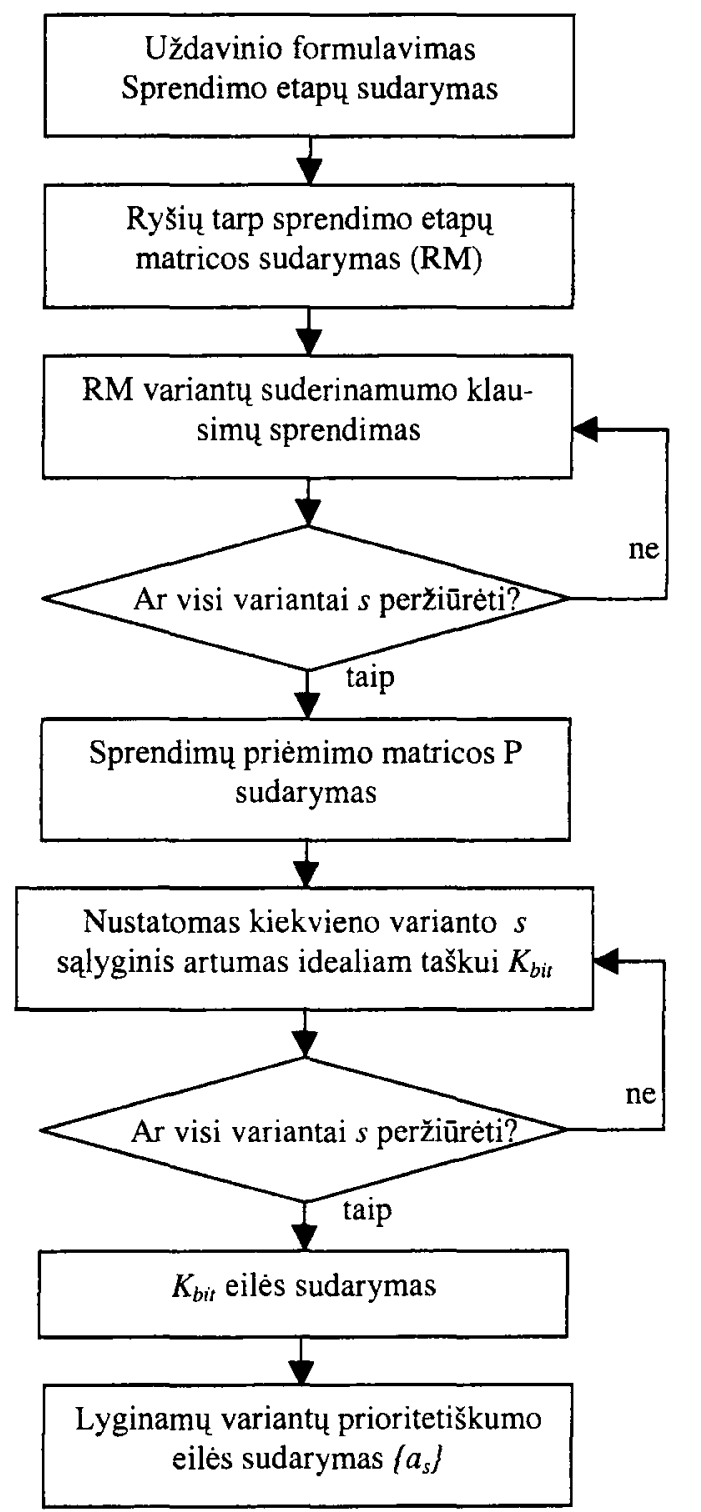

2 pav. Variantų prioritetiškumo nustatymo, projektų sintezès kompromiso kompensaciniu modeliu metodo blokinè schema

Fig 2. Block scheme of the project synthesis method using compromise-compensating model

kriterijus, juos reikia paversti bedimensiais. Pagal (2) formule atlikę normalizacija, gauname sprendimų prièmimo matricą $[P]$ :

$$
\bar{x}_{i j}=\frac{x_{i j}}{\sqrt{\sum_{i=1}^{n} x_{i j}^{2}}}, i=\overline{1, n} ; j=\overline{1, m} .
$$

2 etapas. Svertinès normalizuotos sprendimų matri$\cos$ sudarymas. Matrica $[P]$ dauginama iš kriteriju reikšmingumų vektoriaus $\left[P^{*}\right]=[P] q$. Jei reikšmingumo reikšmių nèra, matrica $[P]$ imama be pakeitimų $\left[P^{*}\right]=[P]$. 
3 etapas. Nustatomi idealus ir neigiamas idealus variantai. Idealus variantas nustatomas pagal (3) formulę:

$a^{+}=\left\{\left[\left(\max _{i} f_{i j} / j \in J\right),\left(\min _{i} f_{i j} / j \in J^{\prime}\right)\right] / i=\overline{1, m}\right\}=$

$=\left\{f_{l}^{+}, f_{2}^{+}, \ldots, f_{n}^{+}\right\}$,

čia $J$ - aibé rodiklių (maksimizuojamu, mažoruojamu), kurių geriausios reikšmès - didžiausios; $J^{\prime}$ - aibè rodikliu (minimizuojamu̧ minoruojamy), kuriq geriausios reikšmès - mažiausios. Sudaromas neigiamas idealus variantas pagal (4) formulę:

$a^{-}=\left\{\left[\left(\min _{i} f_{i j} / j \in J\right),\left(\max _{i} f_{i j} / j \in J^{\prime}\right)\right] / i=\overline{1, m}\right\}=$ $=\left\{f_{I}^{-}, f_{2}^{-}, \ldots, f_{n}^{-}\right\}$,

$a^{+}, a^{-}$- atitinkamai geriausiu ir blogiausiu kriteriju reikšmių variantai.

4 etapas. Tarp lyginamų variantu nustatomi atstumai. Atstumas tarp $a_{i}$ ir $a^{+}$idealaus varianty nustatomas pagal (5) formulę:

$$
L_{i}=\sqrt{\sum_{j=I}^{n}\left(f_{i j}-f_{j}^{+}\right)^{2}} ; \quad \forall i ; \quad i=\overline{1 m} .
$$

Atstumas tarp $i$-tojo ir neigiamo idealaus variantu apskaiciuojamas pagal (6) formulę:

$$
L_{i}^{-}=\sqrt{\sum_{j=1}^{n}\left(f_{i j}-f_{j}^{-}\right)^{2}} ; \quad \forall i ; \quad i=\overline{1, m} \text {. }
$$

5 etapas. Nustatomas salyginis lyginamy variantu artumas idealiam. Sąlyginis $a_{j}$ varianto artumas idealiam $a^{+}$variantui $K_{\text {biri }}$ nustatomas pagal (7) formulę:

$$
K_{b i t i}=\frac{L}{L_{i}^{+}+L} .
$$

Nesunku pastebèti, kad $0 \leq K_{\text {biti }} \leq 1$, be to,

$$
K_{\text {biti }}=\left\{\begin{array}{l}
1, \quad \text { jeigu } a_{i}=a^{+} \\
0, \quad \text { jeigu } a_{i}=a^{-}
\end{array} .\right.
$$

Juo $K_{\text {biti }}$ reikšmè artimesnè vienetui, tuo $a_{i}$ variantas arčiau $a^{+}$varianto. Suformuojama variantų prioritetiškumo eilè $a$. Kriteriju prioritetiškumo eilè sudaroma pagal $K_{b i t}$ kriterijaus reikšmes. Geriausias variantas - turintis didžiausią šio kriterijaus reikšmę.

Variantu prioritetiškumui nustatyti gali būti taikomi ir kiti daugiakriterinio įvertinimo metodai.
Kriteriju pradiniams reikšmingumams nustatyti taikomas ekspertinis metodas, aprašytas [7], [2], [8] darbuose. Atlikus ekspertizę, gauti $t_{j k}$ vertinimų rinkiniai apdorojami statistiškai. Šiuo atveju vidutinè kriterijaus ivertinimo reikšmè $t_{j}$ nustatoma pagal formules (8):

$$
\overline{t_{j}}=\frac{\sum_{k=1}^{r} w_{k} t_{j k}}{\sum_{k=1}^{r} w_{k}}, \quad \text { arba } \overline{t_{j}}=\frac{\sum_{k=1}^{r} t_{j k}}{r},
$$

čia $w_{k}-k$ eksperto autoriteto koeficientas; $t_{j k}-k$ eksperto atliktas $j$ rodiklio ivertinimas; $r$ - ekspertų skaicius.

Ekspertizès patikimumą apibūdina variacija (9):

$$
\beta_{j}=\sigma: \overline{t_{j}},
$$

čia $\sigma$-vidutinè kvadratinè ekspertinių ịvertinimų sklaida, nustatoma pagal formulę (10):

$$
\sigma^{2}=\frac{1}{r-1} \sum_{k-1}^{r}\left(t_{k}-\overline{t_{j}}\right)^{2} .
$$

čia $\sigma^{2}$ - ekspertiniu ivertinimų dispersija.

Ekspertizés patikimumas išreiškiamas ekspertu nuomoniu konkordacijos koeficientu (11), apibūdinančiu individualiy nuomonių sutapimo lygi:

$$
\begin{gathered}
W=\frac{12 S}{r^{2}\left(n^{3}-n\right)-r \sum_{k-1}^{r} T_{k}}, \\
S=\sum_{j=1}^{n}\left[\sum_{k=1}^{r} t_{j k}-\frac{1}{n} \sum_{j=1}^{n} \sum_{k=1}^{r} t_{j k}\right]^{2},
\end{gathered}
$$

čia $S$ - kiekvieno kriterijaus ivertinimo rezultatų nukry pimo kvadratų suma, čia $T_{k}-k$ ranžiruotéje susijusių rangų rodiklis (13):

$$
T_{k}=\sum_{l=1}^{H_{l}}\left(h_{l}^{3}-h_{l}\right)
$$

cia $H_{l}$ - lygiu rangu grupių skaičius $k$ ranžiruotèje; $h_{l}$ lygiu rangu $l$ susijusių rangu grupeje skaicius, ivertinant $k$ ekspertui; $t_{j k}-k$ eksperto $j$ kriterijui priskiriamas rangas; $r$ - ekspertų skaicius; $\boldsymbol{n}$ - ịvertinamų kriteriju skaicius.

Jei nèra susijusių rangu, konkordacijos koeficientas nustatomas pagal formulę (15):

$$
W=\frac{12 S}{r^{2}\left(n^{3}-n\right)} .
$$

Konkordacijos koeficientas lygus 1 , jei visos ekspertụ ranžiruotès vienodos; lygus 0 , jei visos ranžiruotès skirtingos. 
Konkordacijos koeficiento reikšmingumas nustatomas pagal formulę (16):

$$
\chi^{2}=\frac{12 S}{m(n+1)-\frac{1}{n-1} \sum_{k=1}^{r} T_{k}} .
$$

Jei remiantis šia formule apskaičiuota $\chi^{2}$ reikšmè, priklausanti nuo laisvumo laipsnių skaičiaus bei nustatyto reikšmingumo lygio, didesnè nei $\chi_{\text {lent }}^{2}$ (pagal lentelę), ekspertų ranžiruočiu hipotezè priimama. Kitaip, jei $\chi^{2}<\chi_{\text {lent }}^{2}$ - laikoma, kad ekspertų nuomonès nesuderintos ir iš esmès skiriasi.

\section{Lenkų namy̨ efektyviausių konstrukcinių elementų parinkimas, taikant sintezès kompromiso kompensa- cinio modelio metodą}

Lenkų namu, statomų Naugarduko gatvejje, efektyviausiu konstrukcinių elementu parinkimo sprendimas vykdomas trimis etapais:

- pirmuoju etapu renkami duomenys (nustatomi projekte dalyvausiantys kriterijai, surenkami duomenys apie alternatyvas, sudaromos ryšio lentelès) ir suvedami $\mathfrak{i}$ duomenų bazę;

- antruoju etapu, remiantis turimais duomenimis, yra ruošiami duomenys skaičiavimams, padedant ekspertams ivedami trūkstami neapibréžti duomenys i duomenu bazę;

- trečiuoju etapu vykdomas sprendimas sintezès kompromiso kompensaciniu modeliu SKK 3. Atliekama sudarytų alternatyvų daugiakriterinè analizè, nustatomas alternatyvu prioritetiškumas ir naudingumo lygis.

Pirmuoju etapu pasirenkami sprendimo prièmimo objektai. Šiuo konkrečiu atveju buvo pasirinkti 5 konstrukciniai elementai: išorès sienos, pamatai, stogo dangos, vidinès pertvaros ir stogai (2-6 pradinių duomenų lentelès).

Išorès sienu konstrukcinio sprendimo variantu parinkimas. Sieny variantai sprendimui priimti buvo pasirinkti remiantis ankstesne tokiu pastatu statybos patirtimi, tik reikejo nustatyti efektyviausią mūrinès trisluoksnès konstrukcijos sprendima. Tolesnei analizei buvo pasirinkti 6 mürinių trisluoksniu išorès sienų pradinių duomenu variantai ( 1 lentelè). Juos apibūdina 9 kriteriju sistema: piniginè (ar ne piniginè) išraiška, kriteriju matavimo vienetai, minimizuojamas ar maksimizuojamas kriterijus ir pradiniai reikšmingumai (2 lentelè). Kaina pasirenkama norint isitikinti, kiek kainuos pasirinkta alterna- tyva (skaiciuojama $\mathrm{Lt}^{\mathrm{m}} \mathrm{m}^{3}$ ). Darbo imlumas lemia darbų spartą ir patogumą (balais). Šilumos varža nusako pastato būsimą temperatūrini režimą (matuojama $\mathrm{m}^{2} \mathrm{~K} / \mathrm{W}$ ). Garso izoliacija vertinama $D b$, o laikomoji galia - MPa. Kiti kriterijai - estetika, kenksmingumas sveikatai, ilgaamžiškumas, eksploatavimo išlaidos - vertinami balais. Kuo didesnis balas vertinant estetiką ir ilgaamžiskumą, tuo geresnè kriterijaus reikšmè. Ir kuo mažesnis balas vertinant kenksmingumą sveikatai bei eksploatavimo išlaidas, tuo taip pat bus geresne kriterijaus reikšmè.

Paanalizavę lyginamus variantus (1 lentelè) matome, kad kiekviena alternatyva turi savo pliusu ir minusu, palyginti su gretimais variantais. Pvz., 1 varianto yra mažiausia kaina, tačiau 2 variantui reikia mažiausio darbo imlumo, 3 variantas yra mažiausiai kenksmingas sveikatai, o 1 variantas yra stiprumo etalonas.

1 variantas - tinkas, silikatinès plytos $120 \mathrm{~mm}$, akmens vata $150 \mathrm{~mm}$, silikatines plytos $250 \mathrm{~mm}$, tinkas;

2 variantas - tinkas, silikatinés plytos $120 \mathrm{~mm}$, putu polistirolas $150 \mathrm{~mm}$, silikatinè plytos $250 \mathrm{~mm}$, tinkas;

3 variantas - keraminès plytos $120 \mathrm{~mm}$, akmens vata $150 \mathrm{~mm}$, keraminiai blokeliai $250 \mathrm{~mm}$, tinkas;

4 variantas - apdailos plytos $90 \mathrm{~mm}$, akmens vata $150 \mathrm{~mm}$, silikatinès plytos $250 \mathrm{~mm}$, tinkas;

5 variantas - tinkas, silikatines plytos $120 \mathrm{~mm}$, akmens vata $75 \mathrm{~mm}$, akytojo betono blokeliai $300 \mathrm{~mm}$, tinkas;

6 variantas - tinkas, silikatines plytos $120 \mathrm{~mm}$, akmens vata $150 \mathrm{~mm}$, silikatines plytos $120 \mathrm{~mm}$, tinkas.

Duomenys suvedami $\mathfrak{i}$ uždaviniui skirtą duomenų bazę.

Toliau, remiantis turima informacija ir pasitelkus ekspertus, nustatomi šiai sistemai kriteriju pradiniai reikšmingumai. Tam yra taikomi ekspertiniai metodai ekspertinis arba porinio palyginimo ekspertinis metodas.

Šio uždavinio sprendimui priimti taikytas ekspertinis metodas. Išspausdinamos parengtos ekspertinès formos (3 pav.) ir išdalijamos ekspertams.

Suvedus duomenis yra vykdomas sprendimas. Atlikus sprendimą ekspertiniu metodu, galima gautus rezultatus suvesti i duomenų bazę. Pradiniai duomenys ir gauti rezultatai, sprendimą priimant ekspertiniu metodu pagal (9-16 formules), pateikti (4 pav.). 
1 lentelè. Išorès sienų daugiakriterinio îvertinimo variantai

Table 1. Primary estimated data of the comparable main wall variants

\begin{tabular}{|l|c|c|c|c|c|c|c|c|c|c|}
\hline \multicolumn{1}{|c|}{ Kriterijus } & Pinigai & $\begin{array}{c}\text { Matavimo } \\
\text { vnt. }\end{array}$ & $\begin{array}{c}\text { Min ar } \\
\text { Max }\end{array}$ & $\begin{array}{c}\text { Pradine } \\
\text { reiǩme }\end{array}$ & $\begin{array}{c}1 \text { va- } \\
\text { riantas }\end{array}$ & $\begin{array}{c}2 \text { va- } \\
\text { riantas }\end{array}$ & $\begin{array}{c}3 \text { va- } \\
\text { riantas }\end{array}$ & $\begin{array}{c}4 \text { va- } \\
\text { riantas }\end{array}$ & $\begin{array}{c}5 \text { va- } \\
\text { riantas }\end{array}$ & $\begin{array}{c}6 \text { va- } \\
\text { riantas }\end{array}$ \\
\hline Kaina & $\$$ & $\mathrm{Lt}^{3} \mathrm{~m}^{3}$ & - & 0,92 & 131,0 & 136,0 & 126,0 & 142,0 & 120,0 & 116,0 \\
\hline Darbo imlumas & - & Balai & - & 0,56 & 0,70 & 0,65 & 0,90 & 0,80 & 0,75 & 0,70 \\
\hline Šilumos varža $(R)$ & - & $\mathrm{m}^{2} \mathrm{~K} / \mathrm{W}$ & + & 0,72 & 3,76 & 3,46 & 3,70 & 3,70 & 3,83 & 3,47 \\
\hline Garso izoliacija & - & $\mathrm{dB}$ & + & 0,42 & 0,85 & 0,75 & 0,90 & 0,82 & 0,80 & 0,70 \\
\hline Laikomoji galia & - & Balai & + & 0,68 & 1,80 & 1,80 & 1,50 & 1,80 & 0,80 & 0,80 \\
\hline Estetika & - & Balai & + & 0,36 & 1,00 & 1,00 & 0,90 & 0,85 & 1,00 & 1,00 \\
\hline Medž. kenksmingumas sveikatai & - & Balai & - & 0,56 & 0,85 & 0,87 & 0,80 & 0,85 & 1,00 & 0,85 \\
\hline Ilgaamžiskumas & - & Balai & + & 0,56 & 1,00 & 0,90 & 0,80 & 0,85 & 0,85 & 0,90 \\
\hline Eksploatacijos isłlaidos & $\$$ & Balai & - & 0,82 & 0,80 & 0,80 & 0,80 & 0,85 & 0,90 & 0,95 \\
\hline
\end{tabular}

2 lentelè. Išorès sienas apibûdinančių kriterijų aprašymas

Table 2. Description of the main walls criterions system

\begin{tabular}{|c|c|}
\hline Kriterijus & Kriterijaus apibūdinimas \\
\hline Kaina & Ivertina $1 \mathrm{~m}^{3}$ kainą \\
\hline Darbo imlumas & $\begin{array}{l}\text { Tai darbo patogumas ir greitumas. Ivertina, kiek vienas mürininkas vidutiniškai išmūrija per } \\
\text { vieną darbo dieną }\end{array}$ \\
\hline Šilumos varža $(R)$ & $\begin{array}{l}\text { Pagal Šiuolaikinius reikalavimus šilumos varža išorinių sienų konstrukcijai turi būti ne mažes- } \\
\text { ne kaip } 3\end{array}$ \\
\hline Garso izoliacija & Kadangi pastatas statomas prie gatvès, tai svarbi garso izoliacija \\
\hline Laikomoji galia & $\begin{array}{l}\text { Pastato laikanciujų sienų aukštis yra } 15 \mathrm{~m} \text {. Taigi pasirenkama sienos konstrukcija turi būti } \\
\text { tokia, kad pastatas būtų stiprus }\end{array}$ \\
\hline Estetika & $\begin{array}{l}\text { Pasirinkta konstrukcija turi atitikti vietos suplanavimą ir reikalavimus (pvz., fasadas, aukštis ir } \\
\text { t. t.). Turi büti suderinta su užsakovu ir architektu }\end{array}$ \\
\hline Kenksmingumas sveikatai & $\begin{array}{l}\text { Tai naudojamų medžiagų kenksmingumas eksploatacijos ir statybos metu. Reikia stengtis nau- } \\
\text { doti kuo daugiau natūralių medžiagų }\end{array}$ \\
\hline Ilgaamžiskumas & Tai medžiagų savybè laikui bėgant neprarasti pirminių savybių \\
\hline Eksploatacijos islaidos & Tai papildomų išlaidų, kurių reikès eksploatacijos metu, atsiradimas \\
\hline
\end{tabular}

Rezultatai eksperto pageidavimu gali būti išsaugomi nuo 0 iki 1 , tai ir yra reikšmingumai 0,$1643 ; 0,1 ; 0,1286$; 0,$0750 ; 0,1214 ; 0,0643 ; 0,100 ; 0,100 ; 0,1464$ arba vidutinių rangu reikšmès 9,$2 ; 5,6 ; 7,2 ; 4,2 ; 6,8 ; 3,6 ; 5,6 ; 5,6$; 8,2 . Nagrinejjamu atveju yra imamos apskaičiuotos vidutiniu rangu reikšmès.

Pamatu konstrukcinio sprendimo variantu parinkimas (3 lentelè).

1 variantas - stulpiniai pamatai;

2 variantas - gręžtiniai pamatai;

3 variantas - poliniai pamatai;

4 variantas - juostiniai-monolitiniai pamatai;

5 variantas - juostiniai-surenkamieji pamatai.

Projektuojant Lenku namų pastatą buvo problematiška pasirinkti pamatu ir viso pastato konstrukcini spren- dimą. Pastato centrinejje dalyje numatomos irengti koncertụ salès, tad ten turètų būti karkasas su rygeliais ir santvaromis. Karkasiniam pastatui daromi: stulpiniai, gręžtiniai ir poliniai pamatai.

Pamato išilginès sienos irgi galètų büti karkasinès. Tačiau šalia yra šaligatvis, važiuojamoji kelio dalis su troleibusų linija, tai reikettu imtis ypatingy saugumo reikalavimu. Be to, po didžiaja pastato dalimi numatytas rūsys, o tai labai komplikuoja ir brangina karkasiniam pastatui siūlomų pamatų irengima. Taigi išilginéms pastato sienoms buvo pasiūlyta irengti juostinius pamatus (surenkamuosius arba monolitinius).

Stogo konstrukcijos ir dangos variantu parinkimas (4 lentelè). Šiam objektui suprojektuotas šlaitinis stogas turi būti apsildytas, nes bus irengiama gyvenama pastogè. 


\begin{tabular}{|c|c|c|c|c|c|c|c|c|c|}
\hline Ekspertai & \multicolumn{9}{|c|}{ Kriterijus } \\
\hline Pavardè, vardas & KR 1 & KR 2 & KR 3 & $\mathrm{KR} 4$ & KR 5 & KR 6 & $\mathrm{KR} 7$ & $\mathrm{KR} 8$ & KR 9 \\
\hline \multicolumn{10}{|l|}{ Ekspertas 1 } \\
\hline \multicolumn{10}{|l|}{ Ekspertas 2} \\
\hline \multicolumn{10}{|l|}{ Ekspertas 3} \\
\hline \multicolumn{10}{|l|}{ Ekspertas 4} \\
\hline \multicolumn{10}{|l|}{ Ekspertas 5} \\
\hline Kaina & & KR 6 & Estetik & & & & & & \\
\hline Darbo imlumas & & $\mathrm{KR} 7$ & Medži & gu kenl & smingu & mas sve & ikatai & & \\
\hline Silumos varža $(R)$ & & KR 8 & Ilgaam & Eiškume & & & & & \\
\hline Garso izoliacija & & KR 9 & Eksplo & atacinés & islaido & & & & \\
\hline KR 5 Laikomoji galia & & & & & & & & & \\
\hline
\end{tabular}

3 pav. Ekspertiné forma, skirta išrès sienų pradiniams reikšmingumams nustatyti ekspertiniu metodu

Fig 3. Expert form for data input of main walls primary importance of criteria

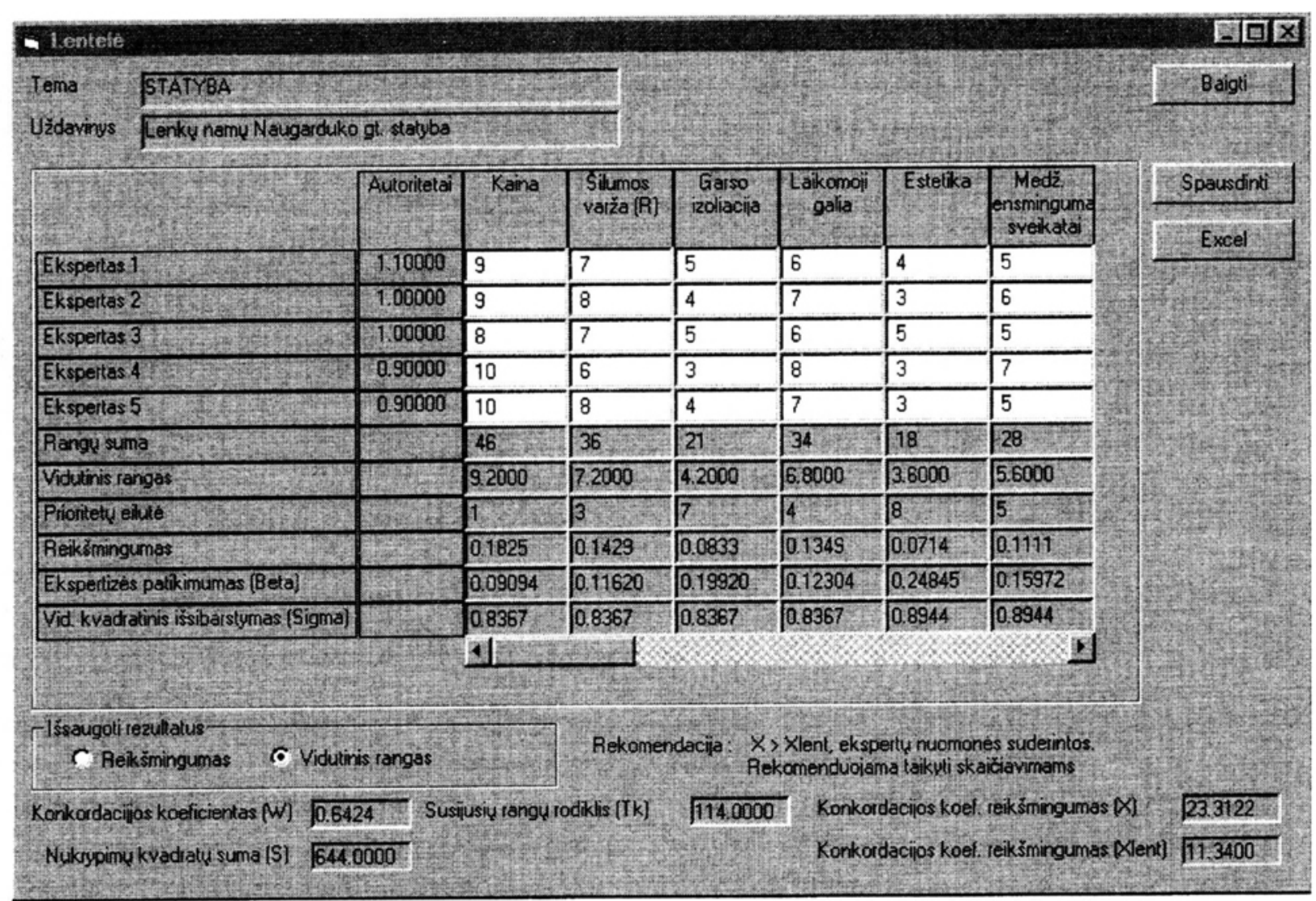

4 pav. Išrès sienų kriterijų pradinio reikšmingumo nustatymo, duomenų ir skaičiavimo rezultatai

Fig 4. Results of estimation of the primary importance of criteria for the main walls

Stogo konstrukcijai apšiltinti numatoma naudoti $200 \mathrm{~mm}$ PAROC akmens vatos plokštę ( 2 sl. po $100 \mathrm{~mm}$ perrišant).

Stogo šlaito nuolydis $\left(35^{\circ}\right)$ tinka visu tipų dangoms. I skaičiavimams pasirinktų variantų $1 \mathrm{~m}^{2}$ kainą itraukta tik viršutinès dangos kaina ir papildomos išlaidos, susijusios su pagrindines konstrukcijos pakitimais, irengiant vieną iš pasirinktų stogo dangos variantų.

\author{
1 variantas - keraminiu cerpiu danga; \\ 2 variantas - beasbestis šiferis (eternitas); \\ 3 variantas - cinkuota skarda; \\ 4 variantas - bituminès čerpès „Žvynas“ (UAB \\ „Gargždų mida“); \\ 5 variantas - plastiku dengta skarda „Rannila“.
}


3 lentelè. Pamatų daugiakriterinio įvertinimo variantai

Table 3. Primary estimated data of the comparable foundation variants

\begin{tabular}{|l|c|c|c|c|c|c|c|c|c|}
\hline \multicolumn{1}{|c|}{ Kriterijus } & Pinigai & $\begin{array}{c}\text { Matavimo } \\
\text { vnt. }\end{array}$ & $\begin{array}{c}\text { Min ar } \\
\text { Max }\end{array}$ & $\begin{array}{c}\text { Pradine } \\
\text { reiksme }\end{array}$ & $\begin{array}{c}1 \text { varian- } \\
\text { tas }\end{array}$ & $\begin{array}{c}\text { varian- } \\
\text { tas }\end{array}$ & $\begin{array}{c}3 \text { varian- } \\
\text { tas }\end{array}$ & $\begin{array}{c}4 \text { varian- } \\
\text { tas }\end{array}$ & $\begin{array}{c}5 \text { varian- } \\
\text { tas }\end{array}$ \\
\hline Kaina & $\$$ & $1000 \mathrm{Lt}$ & - & 0,58 & 316,3 & 310,9 & 320,2 & 305,3 & 277,6 \\
\hline Darbo imlumas & - & Balai & - & 0,40 & 0,90 & 0,85 & 0,95 & 0,95 & 0,90 \\
\hline Ilgaamžiskumas & - & Balai & + & 0,20 & 0,90 & 0,85 & 0,85 & 1,00 & 0,90 \\
\hline Stiprumas & - & Balai & + & 0,25 & 0,80 & 0,80 & 0,80 & 0,85 & 0,85 \\
\hline Spec. technikos poreikis & - & Balai & - & 0,35 & 0,80 & 0,90 & 0,90 & 0,80 & 0,75 \\
\hline Hidroizoliacinis atsparumas & - & Balai & + & 0,20 & 0,90 & 0,85 & 0,90 & 0,95 & 0,85 \\
\hline Organizavimo sudetingumas & - & Balai & - & 0,10 & 0,95 & 0,75 & 0,85 & 0,90 & 0,85 \\
\hline
\end{tabular}

4 lentelè. Stogo konstrukcijos ir dangos daugiakriterinio ivertinimo variantai

Table 4. Primary estimated data of the comparable roof construction and covering variants

\begin{tabular}{|l|c|c|c|c|c|c|c|c|c|}
\hline \multicolumn{1}{|c|}{ Kriterijus } & Pinigai & $\begin{array}{c}\text { Matavimo } \\
\text { vnt. }\end{array}$ & $\begin{array}{c}\text { Min ar } \\
\text { Max }\end{array}$ & $\begin{array}{c}\text { Pradine. } \\
\text { reikšme }\end{array}$ & $\begin{array}{c}1 \text { va- } \\
\text { riantas }\end{array}$ & $\begin{array}{c}2 \text { va- } \\
\text { riantas }\end{array}$ & $\begin{array}{c}3 \text { va- } \\
\text { riantas }\end{array}$ & $\begin{array}{c}4 \text { va- } \\
\text { riantas }\end{array}$ & $\begin{array}{c}5 \text { va- } \\
\text { riantas }\end{array}$ \\
\hline Kaina & $\$$ & $\mathrm{Lt}^{2} \mathrm{~m}^{2}$ & - & 0,58 & 72,00 & 33,00 & 22,00 & 48,00 & 35,00 \\
\hline Darbo imlumas & - & Balai & - & 0,35 & 0,90 & 1,00 & 0,90 & 0,95 & 0,90 \\
\hline Atsparumas aplinkos poveikiui & - & Balai & + & 0,45 & 1,00 & 0,80 & 0,60 & 0,85 & 0,80 \\
\hline Stiprumas & - & Balai & + & 0,25 & 0,70 & 0,85 & 0,75 & 1,00 & 0,85 \\
\hline Estetika & - & Balai & + & 0,30 & 1,00 & 0,85 & 0,70 & 0,75 & 0,90 \\
\hline Medž. kenksmingumas sveikatai & - & Balai & - & 0,20 & 1,00 & 0,85 & 0,80 & 0,85 & 0,80 \\
\hline Ilgaamžiskumas & - & Balai & + & 0,35 & 1,00 & 0,80 & 0,50 & 0,75 & 0,85 \\
\hline Vietinių medž. panaudojimas & - & Balai & + & 0,25 & 1,00 & 0,80 & 0,80 & 0,95 & 0,60 \\
\hline
\end{tabular}

Langu variantu parinkimas (5 lentelè). Išanalizavus pastata veikiancius veiksnius, buvo pasirinkti triju tipu langai su dvigubu stiklo paketu, paliekant $3 \mathrm{~cm}$ tarpą tarp stiklų. Manoma, kad to pakaks išorès triukšmo lygiui sumažinti. Variantai renkami iš klijuoto medžio, aliuminio ir plastiko rèmų konstrukciju.

1 variantas - klijuoto medžio rèmı konstrukcija, UAB „Rudile“";

2 variantas - klijuoto medžio rèmy konstrukcija, $A B$ „Staliu gaminiai“;

3 variantas - aliuminio rẻmų konstrukcija, UAB „Vorto renovacija";

4 variantas - aliuminio rému konstrukcija, UAB „Virata";

5 variantas - plastiko rèmų konstrukcija, UAB „Plasmeta";

6 variantas - plastiko rèmı̨ konstrukcija, UAB ,Sabonio klubas ir partneriai".

Vidiniu pertvaru variantu parinkimas (6 lentelè). Lenku namu pastatui pasirenkant vidiniu pertvaru kon- strukciją reikejo išspręsti uždavini - pasirinkti lengvo tipo karkasines „Gyproc“ pertvaras ar pertvaroms naudoti tradicines inertines medžiagas. Pasirinktu alternatyvų kriteriju reikšmes leme šios svarbiausios pertvaru savybès bei požymiai:

1. Sanitariniuose mazguose pertvaros turi būti hidroizoliacinès.

2. Sausojo tinko pertvaros pagreitintu statybą kadangi galima anksčiau sumontuoti perdangas ir uždengti stoga, o pertvaras irengti vèliau.

3. Sausojo tinko irengimas sumažintų „šlapius" tinko darbus, kurių sumažinimas ypač aktualus šaltu metų laiku, kai nedžiūva skiedinys, gali peršalti. Tada reikia papildomц išlaidų šildymui, drègmei surinkti, ventiliacijai.

4. Sausojo tinko pertvary irengimas yra brangesnis.

5. Sausojo tinko pertvaru akustinès savybès blogesnès nei inertinių medžiagų.

Prieš parenkant pertvaru variantus buvo atlikta GYPROC metalinio karkaso 24 variantų daugiakriterinè 
analizè ir tolesniems skaičiavimams pasirinkti 8 GYPROC metalinio karkaso variantai bei trys tradiciniai inertinių medžiagų pertvarų variantai.

1 variantas - silikatinès plytos $120 \mathrm{~mm}$, aptinkuota;

2 variantas - keraminès skylètos plytos $120 \mathrm{~mm}$, aptinkuota;

3 variantas - akytojo betono blokeliai $100 \mathrm{~mm}$, aptinkuota;

4 variantas - „Gyproc“ metalinis K 1, profiliai E 70/70 mm, 2 sl. „Gyproc“ gipskartonio plokštes $200 \mathrm{~mm}$, be akmens vatos $\mathrm{M} \mathrm{0}$;

5 variantas - „Gyproc" metalinis $\mathrm{K} 1$, profiliai

E $70 / 70 \mathrm{~mm}, 2$ sl. „Gyproc" ugniai atsparios gipskartonio plokštès $2 \mathrm{p} 00$, be akmens vatos $\mathrm{M0}$
6 variantas - „Gyproc“ metalinis K 1 E 70/70 101 M 30, akm. v.;

7 variantas - „Gyproc" met. K 1 E 42/42 202 M 0; 8 variantas - „Gyproc“ met. K 1 E 70/70 202 M 0; 9 variantas - „Gyproc" met. K 1 E 95/95 202 M 0; 10 variantas - „Gyproc" met. K 1 E 120/120 202 M 0; 11 variantas- „Gyproc" met. K 1 E 42/42 202 M 30, akm. v.

Kitu konstrukciju pradiniai duomenys paruošiami kaip ir išorinių sienu.

Suvedus visus pradinius duomenis (pirmas etapas) ir surinkus papildomą neapibrèžtą informacija, yra pereinama prie trečiojo - pagrindinio sprendimo prièmimo sintezès kompensaciniu modeliu etapo. Atlikus skaiciavimus remiantis suvestais duomenimis ir taikant UniSPS SKK3 metoda, atliekama gautų rezultatų analizè.

5 lentelé. Langu konstrukcijos daugiakriterinio įvertinimo variantai

Table 5. Primary estimated data of the comparable window variants

\begin{tabular}{|l|c|c|c|c|c|c|c|c|c|c|}
\hline \multicolumn{1}{|c|}{ Kriterijus } & Pinigai & $\begin{array}{c}\text { Matavi- } \\
\text { mo vnt. }\end{array}$ & $\begin{array}{c}\text { Min ar } \\
\text { Max }\end{array}$ & $\begin{array}{c}\text { Pradine } \\
\text { reikšme }\end{array}$ & $\begin{array}{c}\text { 1 va- } \\
\text { riantas }\end{array}$ & $\begin{array}{c}2 \text { va- } \\
\text { rantas }\end{array}$ & $\begin{array}{c}3 \text { va- } \\
\text { riantas }\end{array}$ & $\begin{array}{c}4 \text { va- } \\
\text { riantas }\end{array}$ & $\begin{array}{c}5 \text { va- } \\
\text { riantas }\end{array}$ & $\begin{array}{c}6 \text { va- } \\
\text { riantas }\end{array}$ \\
\hline Kaina & $\$$ & $\mathrm{Lt}^{2}$ & - & 0,58 & 650,0 & 730,0 & 730,0 & 900,0 & 820,0 & 760,0 \\
\hline Darbo imlumas & - & Balai & - & 0,11 & 0,85 & 0,90 & 0,95 & 1,00 & 0,90 & 0,95 \\
\hline Siluminis laidumas & - & $\mathrm{m}^{2} \mathrm{~K} / \mathrm{W}$ & - & 0,58 & 1,75 & 1,75 & 1,75 & 1,55 & 1,70 & 1,65 \\
\hline Garso izoliacija & - & $\mathrm{dB}$ & - & 0,23 & 42,00 & 52,00 & 42,00 & 34,00 & 38,00 & 40,00 \\
\hline Atsparumas korozijai & - & Balai & + & 0,23 & 0,90 & 0,85 & 0,95 & 0,90 & 0,95 & 0,90 \\
\hline Estetika & - & Balai & + & 0,30 & 1,00 & 1,00 & 0,90 & 0,90 & 0,75 & 0,80 \\
\hline Medž. kenksmingumas sveikatai & - & Balai & - & 0,36 & 0,80 & 0,80 & 0,85 & 0,80 & 0.95 & 0,95 \\
\hline Ilgaamžiškumas & - & Balai & + & 0,35 & 0,90 & 0,90 & 0,95 & 1,00 & 0,70 & 0,75 \\
\hline Ventiliacines grotelès & - & Balai & + & 0,40 & 0,90 & 1,00 & 0,90 & 0,90 & 0,85 & 0,90 \\
\hline Šviesos pralaidumas & - & Balai & + & 0,11 & 1,00 & 0,95 & 0,85 & 0,80 & 0,90 & 0,95 \\
\hline
\end{tabular}

6 lentelè. Vidinių pertvarų daugiakriterinio ịvertinimo variantai

Table 6. Primary estimated data of the comparable internal wall variants

\begin{tabular}{|l|c|c|c|c|c|c|c|c|c|c|c|c|}
\hline \multicolumn{1}{|c|}{ Kriterijus } & Pinigai & $\begin{array}{c}\text { Matavimo } \\
\text { vnt }\end{array}$ & $\begin{array}{c}\text { Min ar } \\
\text { Max }\end{array}$ & $\begin{array}{c}1 \text { va- } \\
\text { riantas }\end{array}$ & $\begin{array}{c}2 \text { va- } \\
\text { rantas }\end{array}$ & $\begin{array}{c}3 \text { va- } \\
\text { riantas }\end{array}$ & $\begin{array}{c}4 \text { va- } \\
\text { riantas }\end{array}$ & $\begin{array}{c}5 \text { va- } \\
\text { riantas }\end{array}$ & $\begin{array}{c}6 \text { va- } \\
\text { riantas }\end{array}$ & $\begin{array}{c}7 \text { va- } \\
\text { riantas }\end{array}$ & $\begin{array}{c}8 \text { va- } \\
\text { riantas }\end{array}$ & $\begin{array}{c}9 \text { va- } \\
\text { riantas }\end{array}$ \\
\hline Kaina & $\$$ & $\mathrm{Lt} / \mathrm{m}^{2}$ & - & 42,00 & 44,00 & 51,00 & 37,00 & 48,00 & 42,00 & 54,00 & 56,00 & 58,00 \\
\hline Darbo imlumas & - & Balai & + & 0,90 & 0,90 & 0,75 & 0,50 & 0,50 & 0,50 & 0,60 & 0,60 & 0,60 \\
\hline Atsparumas ugniai & - & Balai & + & 1,00 & 0,90 & 0,85 & 0,60 & 1,00 & 0,60 & 1,00 & 1,00 & 1,00 \\
\hline Garso izoliacija & - & Balai & + & 0,85 & 0,90 & 0,85 & 0,60 & 0,60 & 0,65 & 0,70 & 0,70 & 0,70 \\
\hline Stiprumas & - & Balai & + & 1,00 & 0,90 & 1,00 & 0,60 & 0,60 & 0,50 & 0,50 & 0,50 & 0,50 \\
\hline Estetika & - & Balai & + & 1,00 & 1,00 & 0,85 & 0,70 & 0,70 & 0,70 & 0,70 & 0,70 & 0,70 \\
\hline $\begin{array}{l}\text { Medžiagu kenksmingumas svei- } \\
\text { katai }\end{array}$ & - & Balai & + & 0,50 & 0,50 & 0,60 & 0,50 & 0,50 & 0,50 & 0,50 & 0,50 & 0,50 \\
\hline Ilgaamžiškumas & - & Balai & + & 1,00 & 0,95 & 1,00 & 0,70 & 0,70 & 0,70 & 0,70 & 0,70 & 0,70 \\
\hline Išardomumas & - & Balai & + & 0,50 & 0,50 & 0,75 & 0,90 & 0,90 & 0,80 & 0,80 & 0,80 & 0,80 \\
\hline Vandens igeriamumas & - & Balai & + & 0,50 & 0,75 & 0,80 & 0,50 & 0,80 & 0,50 & 0,50 & 0,50 & 0,60 \\
\hline
\end{tabular}


7 lentelè. Efektyviausio konstrukcinio varianto parinkimas UniSPS. Dešimt pirmujų variantų iš 9900 galimų prioritetinè eilutè

Table 7. The final estimated result using variant synthesis UniDSS. The priority line of the best ten variants from 9900 possible

\begin{tabular}{|c|c|c|c|c|c|c|}
\hline Prioritetas & & Variantai & LPlus & LMinus & KBit & NaudL \\
\hline \multirow[t]{5}{*}{1} & 1,00 & $\begin{array}{l}\text { Tinkas, silikatinès plytos } 120 \mathrm{~mm} \text {, akmens vata } 150 \mathrm{~mm} \text {, silikatinés } \\
\text { plytos } 250 \mathrm{~mm}\end{array}$ & 0,0052 & 0,0124 & 0,7042 & 100,00 \\
\hline & 5,00 & Juostiniai-surenkamieji pamatai & & & & \\
\hline & 5,00 & Plastiku dengta skarda ,Ranilla“ & & & & \\
\hline & 1,00 & Klijuoto medžio, UAB „Rudile“ & & & & \\
\hline & 1,00 & Silikatinès plytos $120 \mathrm{~mm}$, aptinkuota & & & & \\
\hline \multirow[t]{5}{*}{2} & 1,00 & $\begin{array}{l}\text { Tinkas, silikatinés plytos } 120 \mathrm{~mm} \text {, akmens vata } 150 \mathrm{~mm} \text {, silikatinès } \\
\text { plytos } 250 \mathrm{~mm}\end{array}$ & 0,0052 & 0,0123 & 0,7037 & 99,93 \\
\hline & 5,00 & Juostiniai-surenkamieji pamatai & & & & \\
\hline & 5,00 & Plastiku dengta skarda „,Ranilla" & & & & \\
\hline & 2,00 & Klijuoto medžio, $\mathrm{AB}$,Staliu gaminiai“ & & & & \\
\hline & 1,00 & Silikatinès plytos $120 \mathrm{~mm}$, aptinkuota & & & & \\
\hline \multirow[t]{5}{*}{3} & 1,00 & $\begin{array}{l}\text { Tinkas, silikatinés plytos } 120 \mathrm{~mm} \text {, akmens vata } 150 \mathrm{~mm} \text {, silikatinès } \\
\text { plytos } 250 \mathrm{~mm}\end{array}$ & 0,0052 & 0,0122 & 0,7018 & 99,66 \\
\hline & 5,00 & Juostiniai-surenkamieji pamatai & & & & \\
\hline & 2,00 & Beasbestis šiferis (eteruitas) & & & & \\
\hline & 1,00 & Klijuoto medžio, UAB „Rudile“ & & & & \\
\hline & 3,00 & Akytojo betono blokeliai $100 \mathrm{~mm}$, aptinkuota & & & & \\
\hline \multirow[t]{5}{*}{4} & 1,00 & $\begin{array}{l}\text { Tinkas, silikatinès plytos } 120 \mathrm{~mm} \text {, akmens vata } 150 \mathrm{~mm} \text {, silikatines } \\
\text { plytos } 250 \mathrm{~mm}\end{array}$ & 0,0052 & 0,0122 & 0,7013 & 99,59 \\
\hline & 5,00 & Juostiniai-surenkamieji pamatai & & & & \\
\hline & 2,00 & Beasbestis šiferis (eternitas) & & & & \\
\hline & 2,00 & Klijuoto medžio, $\mathrm{AB}$ „Stalių gaminiai“ & & & & \\
\hline & 3,00 & Akytojo betono blokeliai $100 \mathrm{~mm}$, aptinkuota & & & & \\
\hline \multirow[t]{5}{*}{5} & 1,00 & $\begin{array}{l}\text { Tinkas, silikatines plytos } 120 \mathrm{~mm} \text {, akmens vata } 150 \mathrm{~mm} \text {, silikatinès } \\
\text { plytos } 250 \mathrm{~mm}\end{array}$ & 0,0053 & 0,0123 & 0,6988 & 99,24 \\
\hline & 1,00 & Stulpiniai pamatai & & & & \\
\hline & 5,00 & Plastiku dengta skarda „Ranilla“ & & & & \\
\hline & 1,00 & Klijuoto medžio, UAB ,Rudilè & & & & \\
\hline & 3,00 & Akytojo betono blokeliai $100 \mathrm{~mm}$, aptinkuota & & & & \\
\hline \multirow[t]{5}{*}{6} & 1,00 & $\begin{array}{l}\text { Tinkas, silikatinés plytos } 120 \mathrm{~mm} \text {, akmens vata } 150 \mathrm{~mm} \text {, silikatines } \\
\text { plytos } 250 \mathrm{~mm}\end{array}$ & 0,0053 & 0,0123 & 0,6983 & 99,16 \\
\hline & 1,00 & Stulpiniai pamatai & & & & \\
\hline & 5,00 & Plastiku dengta skarda „,Ranilla" & & & & \\
\hline & 2,00 & Klijuoto medžio, AB „Stalių gaminiai““ & & & & \\
\hline & 3,00 & Akytojo betono blokeliai $100 \mathrm{~mm}$, aptinkuota & & & & \\
\hline \multirow[t]{5}{*}{7} & 1,00 & $\begin{array}{l}\text { Tinkas, silikatinès plytos } 120 \mathrm{~mm} \text {, akmens vata } 150 \mathrm{~mm} \text {, silikatinès } \\
\text { plytos } 250 \mathrm{~mm}\end{array}$ & 0,0055 & 0,0127 & 0,6982 & 99,16 \\
\hline & 5,00 & Juostiniai-surenkamieji pamatai & & & & \\
\hline & 5,00 & Plastiku dengta skarda „Ranilla“ & & & & \\
\hline & 1,00 & Klijuoto medžio, UAB „Rudile & & & & \\
\hline & 3,00 & Akytojo betono blokeliai $100 \mathrm{~mm}$, aptinkuota & & & & \\
\hline \multirow[t]{5}{*}{8} & 1,00 & $\begin{array}{l}\text { Tinkas, silikatinès plytos } 120 \mathrm{~mm} \text {, akmens vata } 150 \mathrm{~mm} \text {, silikatinès } \\
\text { plytos } 250 \mathrm{~mm}\end{array}$ & 0,0055 & 0,0126 & 0,6978 & 99,09 \\
\hline & 5,00 & Juostiniai-surenkamieji pamatai & & & & \\
\hline & 5,00 & Plastiku dengta skarda „Ranilla“" & & & & \\
\hline & 2,00 & Klijuoto medžio, AB „Staliu gaminiai“" & & & & \\
\hline & 3,00 & Akytojo betono blokeliai $100 \mathrm{~mm}$, aptinkuota & & & & \\
\hline \multirow[t]{5}{*}{9} & 1,00 & $\begin{array}{l}\text { Tinkas, silikatines plytos } 120 \mathrm{~mm} \text {, akmens vata } 150 \mathrm{~mm} \text {, silikatines } \\
\text { plytos } 250 \mathrm{~mm}\end{array}$ & 0,0053 & 0,0122 & 0,6977 & 99,08 \\
\hline & 5,00 & Juostiniai-surenkamieji pamatai & & & & \\
\hline & 5,00 & Plastiku dengta skarda „Ranilla" & & & & \\
\hline & 3,00 & Aliuminio rèmц konstrukcija, UAB „, Vorto renovacija“ & & & & \\
\hline & 3,00 & Akytojo betono blokeliai $100 \mathrm{~mm}$, aptinkuota & & & & \\
\hline
\end{tabular}




\begin{tabular}{|c|c|l|c|c|c|c|}
\hline Prioritetas & \multicolumn{1}{|c|}{ Variantai } & LPlus & LMinus & KBit & NaudL \\
\hline 10 & 1,00 & $\begin{array}{l}\text { Tinkas, silikatinés plytos } 120 \mathrm{~mm}, \text { akmens vata } 150 \mathrm{~mm}, \text { silikati- } \\
\text { nés plytos } 250 \mathrm{~mm}\end{array}$ & 0,0054 & 0,0123 & 0,6968 & 98,95 \\
\hline & 2,00 & Gręžtiniai pamatai & & & & \\
\hline & 5,00 & Plastiku dengta skarda ,Ranilla“ & & & & \\
\hline & 1,00 & Klijuoto medžio, UAB ,Rudile“ & & & & \\
\hline & 3,00 & Akytojo betono blokeliai $100 \mathrm{~mm}$, aptinkuota & & & & \\
\hline
\end{tabular}

Dèl didelès rezultatų apimties (9900 galimų variantu) neimanoma išspausdinti visą rezultatų failą. Taigi yra atliekama tarpiniu „DuomVar“ lentelès rezultatu analize ir parodoma tik dalis galutiniu rezultatu. Atlikus analizę paaiškèjo, kad didžiausią itaką sprendimui priimti turèjo: sienas pasirenkant - kaina $q_{l-1}=0,0104$, stoga pasirenkant - kaina $q_{3.1}=0,009502$, langus pasirenkant - šilumos laidumas $q_{4-3}=0,008259$.

Apibendrinant galima pasakyti, kad remiantis pradiniais 2-6 lenteliy duomenimis pagal ekspertinius metodus bei daugiapakopi SKK3 metodą buvo apskaičiuotas efektyviausias konstrukciniu sprendimy variantas, apimantis išorines sienas, pamatus, stogo dangas, langus bei vidines pertvaras. Ǐ̌ 7 lentelès matyti, kad efektyviausias sprendimas yra:

- $S 1$ tinkas, silikatinès plytos $120 \mathrm{~mm}$, akmens vata $150 \mathrm{~mm}$, silikatinès plytos $250 \mathrm{~mm}$, tinkas;

- P 5 juostiniai-surenkamieji pamatai;

- ST 5 plastiku dengta skarda ,Rannila“;

- LAN 1 klijuoto medžio konstrukcijos, UAB „Rudilé 2 stiklu paketas;

- PER 1 silikatines plytos $120 \mathrm{~mm}$, aptinkuota.

Taigi UniSPS, remdamasi pradiniais duomenimis, ekspertų žiniomis, ekspertiniais metodais ir sintezès SKK3 metodu sudarè 9900 efektyviu konstrukciju parinkimo variantụ ir uždavinio galimų variantų prioritetinę eilutę ( 7 lentelè).

\section{Išvados}

1. Taikant sprendimų paramos sistemą (UniSPS), papildytą sintezès kompromiso kompensaciniu metodu, galima atlikti didesnių uždavinių gilesnę analizę, sujungti smulkius projektus $\mathfrak{i}$ visuma, kur atskiros projekto dalys yra sujungtos tam tikrais menamais teigiamais ar neigiamais ryšiais. Šią visumą galima būtų pavadinti optimaliu uždavinio sprendimu, leidžiančiu pasirinkti tinkamą sprendimą su minimalia rizika.

2. Pritaikius sintezès kompromiso kompensacini metodą praktiškai buvo apskaiciuota Lenkų namų, stato- mų Vilniuje, Naugarduko-Kauno gatvių sankirtoje, 5 konstrukciniai elementai: išorès sienos, pamatai, langai, vidinés pertvaros ir stogai. Atlikus skaiciavimy ir realaus statybos proceso rezultatų analizę matyti, kad buvo panaudoti visi apskaičiuoti konstrukciniai elementai. Taigi galima teigti, kad praktinis panaudojimas atitinka teorinius skaičiavimus ir šia sistema galima naudotis sprendžiant ir kitus praktinius uždavinius.

3. Remiantis Lenkų namu, statomų Vilniuje, Naugarduko-Kauno gatveje, praktika yra sukurta pradinè UniSPS statyboje duomenu baze, apimanti tam tikrus išorès sienu̧, pamatu, langu, vidinių pertvarų ir stogu variantus.

4. Sprendžiant kitus realius uždavinius UniSPS statyboje leidžia gauti jau surinktus duomenu bazès duomenis bei papildyti duomenų bazę lentelemis, variantais, kriterijais, ryšio lentelèmis, duomenimis apie ekspertus ir kt.

\section{Literatũra}

1. E. K. Zavadskas, L. Simanauskas, A. Kaklauskas. Sprendimu paramos sistemos statyboje. Vilnius: Technika, 1999. $236 \mathrm{p}$.

2. E. K. Zavadskas, A. Kaklauskas. Pastatų sistemotechninis ivertinimas. Vilnius: Technika, 1996. 280 p.

3. E. K. Zavadskas, O. Kaplinski, A. Kaklauskas, J. Brzezinski. Expert systems in construction industry. Vilnius: Technika, 1995. $180 \mathrm{p}$

4. G. Ambrasas, A. Kaklauskas, E. K. Zavadskas. Efektyviu projektų kūrimo demonstracinè sistema // Statyba, 1996, Nr. 4(8). Vilnius: Technika, p. 84-100.

5. R. Janušaitis. Sienų šiltinimo alternatyvių sprendimų ỉvertinimas, taikant technologinio tinklinio modelio mazgy „išpjovimo “ metoda // Statyba, 1998, IV t., Nr. 4(2). Vilnius: Technika, p. 161-170.

6. E. K. Zavadskas, V. Šarka. Projektų sintezè sprendimu paramos sistemoje // 6-osios tarptautinès konferencijos "Naujos statybines medžiagos, konstrukcijos ir technologijos", ivykusios Vilniuje $1999 \mathrm{~m}$. gegužès 19-22 d., medžiaga. IV tomas. V.: Technika, 1999, p. 268-273.

7. Э. К. Завадскас. Системотехническая оценка технологических решений строительного производства. Ленинград: Стройиздат, 1991. 257 c.

8. Э. К. Завадскас. Обобщенная системотехническая оценка и определение предпочтительности проектных решений в строительстве // Statyba, 1995, N 4(4). Вильнюс: Техника, 1995, с. 31-39. 
Iteikta 19991120

\section{PROJECT SYNTHESIS USING COMPROMISE- COMPENSATING MODEL IN DECISION SUPPORT SYSTEM IN CONSTRUCTION INDUSTRY}

\author{
V. Šarka, L. Ustinovičius, E. K. Zavadskas
}

\section{Summary}

The primary goal for development of project decision support system is to optimise design of rational lifetime processes of a building. An efficient realisation of construction projects requires analysing their constituent parts in close interdependent relationship.

This can be reached by applying three methods of project synthesis in computer software "Universal decision support system in construction" with database of various construction project variants. Thus for carrying out a multicriteria synthesis of various projects and selecting the highest quality alternatives, it is necessary:

- to develop all feasible alternative variations;

- to develop a system of attributes able to produce a detailed description of the alternatives;

- to calculate values and significances of the attributes;

- to develop relation system between alternative variations.

On a UniDSS methodological basis, a technological model of the selections of the most efficient construction elements (main walls, foundations, roof, windows, internal walls) of the real project, Polish house near Naugarduko-Kaunas street crossing, using synthesis, with compromise-compensating model, was developed.

Vaidotas SARKA. Doctoral student. Dept of Building Technology and Management. Vilnius Gediminas Technical University (VGTU), Saulètekio al. 11, 2040 Vilnius, Lithuania.

A graduate of Vilnius Technical University (1993). Author of 5 publications. Research interests: decision support systems in the construction, technology and organisation of building, computing technology, with purpose creating automated system Universal Decision support system (UniDSS).
Leonas USTINOVIČIUS. Doctor (technical sciences), Associate Professor. Dept of Building Technology and Management. Vilnius Gediminas Technical University (VGTU), Sauletekio al. 11, 2040 Vilnius, Lithuania.

A graduate of Vilnius Civil Engineering Institute (now VGTU) (1982). Doctor (1989). Author of 69 research articles. Research interests: building technology.

Edmundas Kazimieras ZAVADSKAS. Doctor Habil, Professor. Rector of Vilnius Gediminas Technical University. Member of Lithuanian Academy of Sciences. Member of Ukrainian Academy of Technological Cybernetics. Vilnius Gediminas Technical University, Sauletekio al. 11, 2040 Vilnius, Lithuania.

In $1973 \mathrm{Dr}$ degree in building structures. Professor at the Dept of Building Technology and Management. In 1987 Dr Habil degree (building technology and management). Research visits to Moscow Civil Engineering Institute, Leipzig and Aachen Higher Technical Schools. He maintains close academic links with the universities of Aalborg (Denmark), Salford and Glamorgan (Great Britain), Poznan University of Technology (Poland), Leipzig Higher School of Technology, Economics and Culture (Germany) and Aachen Higher Technical School (Germany). Member of international organisations. Member of steering and programme committees of many international conferences. Member of editorial boards of some research journals. Author of monographs in Lithuanian, English, German and Russian. Research interests: building technology and management, decision-making theory, automation in design, expert systems. 